\title{
Lika för alla?
}

\section{Christian Gerdov}

SAMMANDRAG: När Moderaterna inför riksdagsvalet 2018 lanserade sin nya valslogan "Lika för alla" var det till mångas förvåning, även inom partiet självt, eftersom den förde tankarna till idén om social jämlikhet, vilket vanligtvis förknippas med den politiska vänstern. I sin artikel visar Christian Gerdov emellertid hur det inom kort klargjordes att det inte var social jämlikhet som Moderaterna avsåg, utan snarare hur talet om lika för alla grundade sig i den liberala föreställningen om jämlikhet i frihet, liksom jämlikhet inför lagen. Vidare låg vikten vid skyldigheter, såsom plikten att arbeta. De sociala rättigheterna, som vann insteg efter andra världskriget, har ersatts av det nyliberala projektet för valfrihet, där medborgaren förvandlas till en självförverkligande entreprenör. Det universella subjektet $i$ talet om lika för alla visar sig även vara partikulärt, eftersom svenskhet och svenska värderingar betonas och kontrasteras mot det hotfulla "Andra". Moderaternas slogan påminner därför om Orwellskt nyspråk där alla förklaras vara jämlika, men där somliga är mer jämlika än andra.

NYCKELORD: Moderaterna; medborgarskap; rättigheter; jämlikhet; frihet; nyliberalism; valslogan.

PUBLICERINGSHISTORIK: Originalpublicering.

CHRISTIAN GERDOV är doktorand i historia vid Mittuniversitetet.

E-POSTADRESS: christian.gerdov@miun.se

FÖRSLAG PÅ KÄLLANGIVELSE:

Gerdov, Christian (2019) "Lika för alla?", i Arkiv. Tidskrift för sambällsanalys, nr Io, s. 7I-86.

DOI: https://doi.org/I0.13068/2000-6217.I0.3

(C) Christian Gerdov/Arkiv förlag \& tidskrift 2019 (publicerad 28 maj 20I9)

Artikeln distribueras enligt en upphovsrättslicens från Creative Commons:

Erkännande-Ickekommersiell-IngaBearbetningar 3.o Unported, som medger fri ickekommersiell användning och spridning i oförändrat skick så länge källan anges. 
Arkiv. Tidskrift för samhällsanalys är en sakkunniggranskad vetenskaplig tidskrift för samhällsvetenskap och historia. Samtliga artiklar publiceras fritt tillgängliga på:

$$
\text { www.tidskriftenarkiv.se }
$$

Beständig länk, DOI: https://doi.org/IO.13068/2000-62I7

Den här artikeln finns tillgänglig i följande format:

PDF: via beständig länk, DOI: https://doi.org/IO.I3068/2000-6217.IO.3

TRYCK: ingår i bokutgåva av numret, ISBN: 978 9I 79243272

Grafisk utformning och sidnumrering är identisk i pdf och tryck.

Samtliga artiklar i nr ıo (2019) nås via beständig länk, DOI: https://doi.org/IO.I3068/2000-6217.10

Arkiv. Tidskrift för sambällsanalys

ISSN: 2000-6217 (för elektronisk resurs)

ISSN: 2000-6225 (för tryckta nummer)

ges ut av

Stiftelsen Arkiv för främjande och spridning av samhällsvetenskaplig och historisk forskning

genom

Arkiv förlag \& tidskrift

Box 1559

SE-22I OI Lund

BESÖK: L Gråbrödersg 3 c, ipg

TEL: 046-I3 3920

ARKIV FÖRLAG: arkiv@arkiv.nu·www.arkiv.nu

TIDSKRIFTEN ARKIV: red@tidskriftenarkiv.se.www.tidskriftenarkiv.se

ANSVARIg UTGIVARE \& CHEFREDAKTÖR: Sven Hort

AdMinistrativ Redaktör: David Lindberg

Redaktörer: Paavo Bergman, Per Dannefjord, Lisa Kings,

Zhanna Kravchenko, Anna-Maria Sarstrand Marekovic 


\section{Lika för alla?}

\section{CHRISTIAN GERDOV}

Vi anser dessa sanningar för självklara: att alla människor är skapade jämlika; att de av sin Skapare begåvats med vissa oförytterliga rättigheter; att bland dessa är liv, frihet och strävande efter lycka.

- Ur den amerikanska självständighetsförklaringen. ${ }^{\mathrm{I}}$

Det var måhända inte enbart Moderaternas partisekreterare Gunnar Strömmer som var "nära att sätta kaffet i vrångstrupen" när partiets nya valslogan presenterades under maj månad 2018: "Lika för alla". ${ }^{2}$ Partisekreterarens infall (att sätta kaffet i vrångstrupen) vittnade om sloganens radikala, rentav revolutionära, potential - vilket är förståeligt med hänsyn till att den idéhistoriska bakgrund som det anspelas på är arvet från såväl den amerikanska som franska revolutionen under I70o-talets slut. Men idéerna präglades redan då av inbördes motsättningar och motsägelser, dels mellan frihet och jämlikhet, dels i avseende på vilka dessa "alla" (som ligger implicit i förklaringen om de mänskliga och medborgerliga rättigheterna) de facto avser. Med hänsyn till detta vore det därför, som Ernesto Laclau och Chantal Mouffe påpekat apropå den nyliberala och nykonservativa diskursen: "ett misstag att underskatta dessa försök att omdefiniera idéer som 'frihet', 'jämlikhet', 'rättvisa' och 'demokrati'". ${ }^{3}$ Moderaternas valslogan bör således skärskådas såväl ur ett samtidsperspektiv som ett längre idéhistoriskt perspektiv. 
ARKIV | NR IO | VALET 2018

\section{En idéhistorisk bakgrund}

Som Norberto Bobbio hävdat är den filosofiska förutsättningen för den liberala staten naturrättsskolans idé om de mänskliga rättigheterna som en av naturen given ordning, det vill säga att alla människor utan åtskillnad är av naturen födda fria och jämlika. ${ }^{4}$ Men det finns en viss ironi i att de så kallade naturliga och oförytterliga rättigheter som tillskrevs människan i den amerikanska självständighetsförklaringen och senare den franska förklaringen om de mänskliga och medborgerliga rättigheterna tillförsäkrades genom lagen, som trots allt är en produkt av den sociala ordningen - varför "naturliga rättigheter" intet annat är än vad de lagstiftande medborgarna ansåg som "naturligt". ${ }^{5}$ Den liberala idétraditionen tenderar dock att föreställa sig ett pre-politiskt tillstånd med naturliga rättigheter, där individerna gick samman och slöt ett kontrakt genom en samhällelig sammanslutning vars primära syfte var att garantera och skydda dessa rättigheter. ${ }^{6}$ Det borgerliga samhället blir således ett slags förlängning eller snarare en utvidgning av det pre-politiska tillståndet, och framstår som "naturligt" i förhållande till andra sätt att organisera samhället på - något Karl Marx ironiserade över i Filosofins elände.?

Idén om detta "samhällskontrakt" mellan individer framkommer hos John Locke i Andra avhandlingen om styrelseskicket (I689) liksom hundra år senare i den franska nationalförsamlingens förklaring (I789). ${ }^{8}$ Som Étienne Balibar påpekar handlar det om ett slags ömsesidigt förhållande där medborgare förlänar varandra rättigheter och skyldigheter. Samtidigt reser det en fråga kring rättighetsdiskursens "dualitet" och hur denna kan eller bör tolkas, det vill säga tillskansar sig "vi” oss dessa naturliga rättigheter i första hand såsom människa eller medborgare?9 Eller med andra ord, som Marx skarpögt frågade: "Vem är denna människa som skiljer sig från medborgaren?”

Det universalistiska anspråket i den amerikanska och franska revolutionens idéer kringskars redan i tillkomstögonblicket eftersom idén om denna människalmedborgare utgick från den vite och egendomsägande mannen - annars riskerade makten att hamna hos den skräckinjagande "massan". Således fann sig det stora flertalet vara utestängda från såväl det politiska medborgarskapet som det mänskliga, och vann endast insteg i denna gemenskap genom kamp. ${ }^{\text {II }}$ Detta blottade ett glapp, eller 
snarare en avgrund, såväl i de högtidliga förklaringarna som i den franska parollen om frihet, jämlikhet, broderskap (liberté, égalité, fraternité), vilket föranledde Olympe de Gouges att, så att säga, revidera den franska förklaringen och skriva in kvinnan. Slagkraftigt hävdade hon: ”Om kvinnan har rätt att bestiga schavotten, bör hon också kunna bestiga talarstolen." ${ }^{\text {I2 }}$ Historien manar oss därför till att ifrågasätta och kritiskt granska universalistiska deklarationer - vilka är exempelvis dessa "alla" som Moderaterna talar om i sin slogan?

Vi ska nu för ett ögonblick blunda för de formella och informella uteslutningar som existerade och i stället fråga oss vad och vilka dessa fri- och rättigheter var som skulle tillkomma människan/medborgaren. I den franska nationalförsamlingens förklaring kan vi i den andra artikeln läsa följande: "Dessa rättigheter är rätten till frihet, rätten till egendom, rätten till personlig säkerhet och rätten till motstånd mot förtryck." ${ }^{13}$ Häri urskilde Marx en inneboende klassdimension och menade att dessa mänskliga och medborgerliga rättigheter intet annat än tillförsäkrar bourgeoisien deras rättigheter och garanterar dem skydd (särskilt för privategendomen, vars innehav var avgörande för att kunna räknas till de aktiva och beslutsfattande medborgarna). ${ }^{14}$ Dessa olika fri- och rättigheter premierar, enligt Marx, egennyttan och gör medborgarna till isolerade och slutna "monader", eller med andra ord egoister som ser sin nästa såsom ett hinder för självförverkligandet av sin egen persons frihet. ${ }^{15}$ Och i den ekonomiska sfären är, som Bobbio anmärker, begreppen frihet och jämlikhet rentav antitetiska " $i$ den meningen att man inte fullt ut kan förverkliga den ena utan att begränsa den andra". ${ }^{16}$

Detta förhållande mellan frihet och jämlikhet reser, som Bobbio skri-

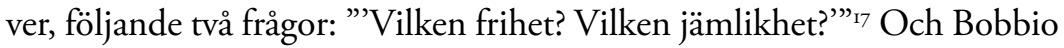
svarar:

Den enda form av jämlikhet som inte bara är förenlig med frihet, såsom den uppfattas i den liberala doktrinen, utan som frihet formligen fordrar, är jämlikhet i fråga om frihet. Därmed menas att var och en bör åtnjuta så mycket frihet som är förenlig med andras frihet, och att var och en kan göra allt som inte kränker andras lika stora frihet. Praktiskt taget ända sedan den liberala statens första stund har denna form av jämlikhet inspirerat två grundläggande principer som kom att formuleras som författningsenliga normer: a) jämlikhet inför lagen; b) allas lika rätt. ${ }^{18}$ 
Det är framför allt dessa principer, och föreställningen om frihet och jämlikhet som tar sin utgångspunkt $\mathrm{i}$ individen (monaden), som leder oss fram till Moderaternas "Lika för alla". Men finns det inte andra möjliga tolkningar av frihet och jämlikhet för alla - något som får moderater att sätta kaffet i vrångstrupen? En möjlighet är att vända på idén om "jämlikhet i fråga om frihet" till "frihet i fråga om jämlikhet" och göra dem båda till förutsättningen för varandra.

För Balibar förutsätter just idén om frihet och jämlikhet varandra de är oskiljaktiga. Till skillnad från en liberal doktrin som ser frihet som det primära och en socialistisk som propagerar jämlikhet i första hand, talar han om en reciprocitet mellan begreppen där det ena förutsätter det andra (ingen frihet utan jämlikhet och ingen jämlikhet utan frihet), vilket fångas in genom det ihopsatta begreppet égaliberté. ${ }^{19}$

Men det kanske mest avgörande är trots allt frågan om vilken frihet och vilken jämlikhet, eller kanske snarare: jämlikhet i vad? ${ }^{20}$ De rättigheter som exempelvis "uppstod" under I700- och I800-talet, främst civila och politiska fri- och rättigheter (såsom likhet inför lagen), kompletterades under I900-talet av vad som kallades sociala rättigheter - vilka utgjorde ett försök att svara på den ekonomiska och sociala utsattheten som växte fram i industrisamhällets spår. ${ }^{21}$ Välfärdsstaternas framväxt och expansion under 1900-talets första hälft är därmed ett talande exempel på utvecklingen och tillskansandet av just de sociala rättigheterna. ${ }^{22}$ Vad man försökte uppnå var ett av Franklin D. Roosevelts mål, i spåren av de amerikanska depressionsåren, som formulerades såsom en "frihet från nöd" (freedom from want) och innebar rättigheten till ett socialt och ekonomiskt tryggat liv. Denna rättighet skrevs även in som en del av FN:s allmänna förklaring om de mänskliga rättigheterna från I948:

Envar äger i sin egenskap av samhällsmedlem rätt till social trygghet och är berättigad till att de ekonomiska, sociala och kulturella rättigheter, som äro oundgängliga för hans värdighet och för en fri utveckling av hans personlighet, förverkligas genom nationella åtgärder och mellanfolkligt samarbete med hänsyn tagen till varje stats organisation och resurser. ${ }^{23}$

Rättigheten till ett socialt och ekonomiskt tryggat liv som eftersträvades (och i viss mån infriades inom de västerländska välfärdsstaterna) kom dock att urholkas alltmer från och med I970-talets kriser, i vilkas 
spår nyliberalismen växte som ideologi och senare segrade genom socialdemokratins skifte till den tredje vägens politik under 1980-talet. På engelska talas det här om en övergång från welfare till workfare, vilket vittnar om arbetslinjens hegemoni där rätten till välfärd $i$ allt högre grad har kopplats till innehavet av ett arbete. De sociala rättigheterna har vittrat bort och betraktas således inte längre som rättigheter, utan snarare som förmåner för den företagsamma individen. ${ }^{24}$ Och parallellt med urholkningen av de sociala rättigheterna och välfärdsstaten har den ekonomiska ojämlikheten, föga förvånande, ökat dramatiskt i västvärlden - i Sverige har den sedan mitten av 1980- till 20I0-talets början ökat mest bland alla OECD-länder. ${ }^{25}$ Hur kommer det sig då att Moderaterna, mot bakgrund av den alltmer ökande sociala ojämlikheten och otryggheten, talar om "Lika för alla" - till synes utan ironi? Och vilka är de rättigheter, skyldigheter och möjligheter som partiet åsyftar i sammanhanget? ${ }^{26}$

\section{Lika för alla: rättigheter, skyldigheter, möjligheter}

Om vi granskar hur Moderaternas politik formuleras i korthet är rättigheterna något diffusa och opreciserade. Den främsta rättigheten tycks här vara att inte betala skatt: "Lärare och sjuksköterskor ska inte behöva betala statlig inkomstskatt." ${ }^{27}$ Rättigheten handlar således om en negativ frihet som innebär en frihet från tvång och förbud, och i förlängningen från statliga ingrepp i det personliga. Denna negativa frihet framgår även vad gäller "barns rättigheter" som lyfts fram med udden riktad mot ickesvenskar, vilka implicit inte anses tillvarata dessa till skillnad från "oss" här i Sverige, eller som partiledaren Ulf Kristersson beskriver det:

[Ett Sverige] där klan inte avgör om den som är född i en kultur, har rätt att själv bli en del av en annan. I vårt land har barn - både pojkar och flickor - rättigheter som deras föräldrar eller släktingar helt enkelt inte förfogar över. ${ }^{28}$

Den politiska debatten har "kulturaliserats" såtillvida att man allt ofta har haft en tydlig adressat med sådan retorik: främlingarna i förorten med sina "moralpoliser" och "parallella lagsystem" ska övervakas och tuktas, men framför allt anpassa sig till "svenska värderingar". ${ }^{29}$ Här ska staten, till skillnad från andra sammanhang, särskilt intervenera. I de "invandrartäta" förorternas (o)uttalade undantagstillstånd tycks det 
endast vara en tidsfråga innan militären sätts in, det vill säga att man går från ord till handling, som en följd av den alltmer polariserade politiska debattens spel om vem som kan överträffa vem i att vara tuffast mot brottslighet (läs: "invandrare")..$^{30}$

Om rättigheterna som avses till synes är få och diffusa är skyldigheterna desto fler och tydliga hos Moderaterna. Skyldigheter (eller plikter) är i sig inget anmärkningsvärt, som Bobbio förklarar är plikten "korrelatet till rättigheten. På samma sätt som det inte finns någon far utan barn och omvänt, så existerar ingen rättighet utan plikt och omvänt." ${ }^{1}$ Men hos Moderaterna representerar skyldigheterna statens auktoritära och repressiva sida (lag och ordning) genom exempelvis löften om fler poliser, skärpta straff, minskad invandring, språkkrav i svenska, integrationsplikt, arbetsplikt och utökad skolplikt. ${ }^{32}$ Jämlikhet, såsom det framstår i Moderaternas tal om "Lika för alla", handlar inte om en social och ekonomisk jämlikhet (som får dem att sätta kaffet i vrångstrupen) utan snarare om likhet inför lagen med de tillhörande skyldigheterna att lyda under såväl den som arbetslinjen (vilken närmast per association upphöjs till lag): "Här ska friheten, lagarna och arbetslinjen gälla." 33

"Den som kan, ska jobba", säger Kristersson och menar vidare att de som kan, men inte jobbar "lever på bidrag", eftersom det tydligen lönar sig mer än att arbeta - vilket anges som grund för att bidragen måste begränsas, och därigenom motivera folk till arbete. ${ }^{34}$ Hela grundidén är således att den som är arbetslös, eller på andra sätt är ekonomiskt och socialt utsatt, måste vara det av egen fri vilja (oavsett exempelvis tillgången till arbete) eftersom det anses vittna om oviljan att ta tillvara på de möjligheter som anses finnas tillgängliga för alla.

En annan jämlikhet som förespeglas i talet om "Lika för alla" är således föreställningen om allas lika förutsättningar, vilket hos Moderaterna formuleras såsom möjligheter, där individen "av egen kraft - men ofta med andras hjälp - från nästan ingenting kan ta sig nästan hur långt som helst". ${ }^{35}$ Det lömska med detta tal om möjligheter är, bland annat, som Callinicos skriver: "implikationen att det gäller för individerna att utnyttja dessa möjligheter." ${ }^{6}$ Diskursen fungerar således som ett implicit skuldbeläggande och ogiltigförklarande av olycka, för hur kan individen vara olycklig när hon har alla möjligheter att vara lycklig? Det handlar 
helt enkelt om ett val. Och inom flera sociala arbetsområden har begreppet valfrihet närmast ersatt talet om jämlikhet.

Moderaterna framhäver hur Sverige ska vara ett land "med frihet att välja sitt liv och med all den mångfald som den friheten skapar". ${ }^{37}$ Som Sven-Eric Liedman anmärker anses individen numera utöva sin frihet genom att göra olika val på marknaden, som nu för tiden sträcker sig från pensioner till läsk i alla tänkbara smaker. ${ }^{38}$ En baksida till dessa otaliga valmöjligheter är att individen hamnar i ett ångestfyllt dilemma: Vilket är rätt val bland mångfalden av val som erbjuds oss? Resultatet visar sig först i efterhand. Det är således ett högriskspel som ingen kan avstå, där livet omvandlas till ett hasardspel med framtiden som insats. ${ }^{39}$ Eller som Liedman skriver: "hur stor är denna frihet när alla dras in i den och tvingas till sina val och även icke-valet är ett val, och vad är friheten värd när aktiekursen störtar mot avgrunden?"40

Här framgår med tydlighet den ojämlikhet, men också den ofrihet, som råder kring våra val. I detta "risksamhälle" är det vissa som tar de stora riskerna medan resten får betala notan för att inte själva riskera allt, vilket framgick i spåren efter finanskrisen 2008 då banker och företag räddades av förmånliga räddningspaket signerade av politikerna men betalade med skattebetalarnas pengar. ${ }^{4 \mathrm{I}}$ Vissa risker ligger helt enkelt bortom vår vetskap - eller med andra ord det faktum att vi ständigt lever i risk, och sällan självvald sådan. Således kunde exempelvis elever för en tid sedan välja gymnasier inom John Bauer-koncernen, helt ovetandes om att de därigenom tog risken att hela deras utbildning skulle sättas på spel när koncernen gick i konkurs på grund av ägarnas "risktagande".

Det den liberala ideologin, med Moderaternas möjligheter, försöker inpränta är att vi i grunden väljer våra liv, och att de val vi gör inte är bundna till några andra faktorer än oss själva och vår egen (vilje)kraft..$^{42}$ Om allt går fel har vi, enligt denna logik, endast oss själva och de val vi gjort att skylla. Med den efterklokes visdom säger man: "Du borde ha agerat (läs: valt) annorlunda!" Eller som Renata Salecl påpekar: ”I själva verket kanske vi har mycket lite frihet att bestämma vad vi ska göra med våra liv, men vad vi än gör så 'behöver' ideologin bilden av att vi skulle ha kunnat agera annorlunda." ${ }^{43}$ Som en talande illustration över valfrihetssambället förklarar hon vidare: 
ARKIV | NR IO | VALET 2OI8

Under den utvecklade kapitalismen har individen befordrats från en proletär slav till en fri konsument som uppfattar sig själv som herre över sitt eget öde och har oändliga valmöjligheter när det gäller att forma sitt eget liv. ${ }^{44}$

Detta vittnar om den trend som Wendy Brown urskiljer där medborgaren blir till en entreprenör över sitt eget liv, eller med andra ord: individen blir sin egen (o)lyckas smed medelst "Aktiebolaget JAG". ${ }^{45}$ Det överensstämmer även med Byung-Chul Hans tes om att vi lever i ett "prestationssamhälle" (till skillnad från disciplinsamhälle), där invånarna "inte längre [är] 'lydnadssubjekt', utan prestationssubjekt". ${ }^{66}$ Detta framgår även av Kristerssons uppfattning om den svenska jämlikhetstanken: "där vad du gör är viktigare än vem du är”. ${ }^{47}$

Samtidigt råder det inga tvivel om att individens (o)lycka faktiskt är beroende av yttre faktorer såsom den globala börsmarknaden liksom den egna nationens ekonomiska välgång. ${ }^{4}{ }^{4}$ Under ytan på den nyliberala ordningens förment frigörande process, med den glada reklambilden av den självförverkligande entreprenörsmedborgaren, vilar en förtäckt styrningsrationalitet. ${ }^{49}$ Eller som Brown påpekar:

medan det nyliberala medborgarskapet låter individen ta hand om sig själv, binder det samtidigt diskursivt individen till helhetens välmående - den kräver hennes trohet och potentiella självuppoffring för nationens bästa eller ekonomiska tillväxt. Detta är den paradoxala inversionen av nyliberal frihet $[\ldots]^{50}$

Medborgaren blir till en vara som konkurrerar på den globala (arbets-) marknaden, och blir vidare ansvarig inte enbart för sin egen utan även för nationens (o)lycka, vilket framkom i Kristerssons "tal till nationen" som sändes på SVT den 30 maj 20I8:

företagare [måste] uppskattas mer än de beskattas. Och vi måste göra det enklare och billigare att anställa dom som inte har haft något jobb förut, eller som inte talar så bra svenska. När stora huvudkontor lämnar landet är Sverige ute på en farlig väg. ${ }^{\text {st }}$

Sänkta skatter för företag ska således ske parallellt med nedskärningar i de sociala rättigheterna (exempelvis "bidragen"s2), samtidigt som de som redan befinner sig på botten ska tvingas att acceptera ännu lägre löner och sämre arbetsvillkor - allt i syfte att nationen återigen ska hamna på rätt 
väg (i motsats till en "farlig väg") och bli konkurrenskraftig och välmående. Det ekonomiska systemet som sådant utmanas inte och det enda valet i valfrihetens envälde som vi inte tycks ha är att avvisa den rådande ordningen. Den ekonomiska tillväxten blir därmed till den heliga ko inför vilken medborgarna förväntas (upp)offra sig själva..$^{53}$

Moderaterna konkluderar sitt budskap med: "Inga undantag, ingen utanför eller bortglömd. Lika för alla." ${ }^{54}$ Men vilka är dessa alla som åsyftas, och är verkligen ingen undantagen, utanför eller bortglömd? Eftersom sloganen lanserades inför det svenska riksdagsvalet bör rimligtvis det alla som åsyftas vara svenska medborgare och inte hela mänskligheten som sådan. Den jämlikhet som alluderas till utgår i sin tur främst från en liberal grund om individens frihet och allas likhet inför lagen, men beaktar inte i någon nämnvärd utsträckning de sociala rättigheterna. Det rådande klassamhället, med ökad "prekaritet" genom lägre löner, försämrade anställningsvillkor och inskränkt strejkrätt, ska bestå och utvidgas genom formeringen av en ny låglöneklass som till stor del ska utgöras av utrikesfödda. 55 Här tydliggörs en åtskillnad mellan etniska svenskar vars status i sin tur blir en rättighetsmarkör gentemot "de Andra” som ställs utanför "oss Alla" ${ }^{56}$ Som Balibar anmärker kan nationens medborgare "övertygas om att deras rättigheter faktiskt existerar om de får se hur främlingarnas rättigheter är underlägsna deras, prekära, eller villkorade av upprepade former av lojalitetsförklaringar" ${ }^{57}$ Dessa främlingar (utrikesfödda eller invandrare) kan formellt sett vara medborgare men rent informellt inneha ett andra rangens medborgarskap..$^{58}$ Vidare framställs dessa "Andra" som ett problem som måste hanteras och kontrolleras, vilket därmed ställer idén om "Lika för alla” i skarpare kontrast i förhållande till de som kan undgå ständig övervakning och hot om statligt ingripande. ${ }^{59}$

Men den kanske mest iögonfallande diskrepansen i talet om lika för alla är flyktingarna, vars utsatta situation och rättsosäkra status vare sig garanterar att de behandlas lika eller som våra likar. ${ }^{60}$ Hannah Arendts skarpa kritik är i det avseendet lika relevant i dag som när det formulerades I95I:

Ingen paradox i samtidspolitiken rymmer en mer bitande ironi än diskrepansen mellan å ena sidan ambitionerna bland välmenande idealister, som envist fram- 
ARKIV | NR IO | VALET 2OI8

härdar i att hävda det "omistliga” i dessa mänskliga rättigheter som åtnjuts bara av medborgare i de mest välmående och civiliserade länderna, och å andra sidan de rättighetslösas egen situation. ${ }^{6 \mathrm{I}}$

Det vore samtidigt ohederligt att här ensamt peka finger åt Moderaterna och bortse från den politiska konsensus som för tillfället råder inom flyktingfrågan, det vill säga: "Stopp!" Det (national)konservativa argumentet bakom är i sin enkelhet rättframt genom betoningen på svenskhet och "traditionella svenska värderingar", medan det liberala argumentet erbjuder en politisk rävsax: Vi ska leva upp till FN:s deklaration om de mänskliga rättigheterna och flyktingkonventionen men detta kan endast ske under förutsättning att lönerna sänks och välfärdsstaten urholkas - budskapet är således att vi inte kan ha båda. Moderaterna och Socialdemokraterna, som här är mycket lika varandra, har förenat de två positionerna. Således betonas till exempel att Sveriges gränser är och fortsatt ska vara tryggade, och inom dessa är det "svenska värderingar" som gäller (det nationalkonservativa argumentet). Välfärdsstaten (vad som återstår av den) ska upprätthållas och förbli intakt genom invandringsstopp (det liberala falska valet), och medelst sin feministiska utrikespolitik har Socialdemokraterna upprätthållit auran av humanism medan Moderaterna med Kristersson i spetsen kan tala om hur deras parti "är djupt förankrat i internationell öppenhet och europeiskt och globalt samarbete" (det liberala idealet) - det vill säga: kapitalet ska fortsatt flöda fritt länder emellan, men inte vissa människor. ${ }^{62}$

Avslutningsvis kan vi därför, för att parafrasera Marx, urskilja det historiska dramats tendens till upprepning: först som tragedi (här i avseende att det "égalibertüra" löftet i de förflutna revolutionerna aldrig infriades), sedan som fars - vilket, som Herbert Marcuse anmärkte, kan vara ännu mer skräckinjagande än tragedin som föregick den. ${ }^{63}$ Moderaternas "Lika för alla” må således alludera till ett revolutionärt arv, men för vid en närmare granskning snarare tankarna till George Orwells Djurens gård från 1945:

\author{
ALLA DJUR ÄR JÄMLIKA \\ MEN SOMLIGA DJUR ÄR MERA \\ JÄMLIKA ÄN ANDRA ${ }^{64}$
}




\section{Noter}

I. "Amerikanska självständighetsförklaringen den 4 juli I776 (Thomas Jeffersons ingress)", 1998 [I776], s. I65.

2. Mellin, ”Nu låter $\mathrm{M}$ som sossar igen”, 2018.

3. Laclau \& Mouffe, Hegemonin och den socialistiska strategin, 2008, s. 235-240 (citat s. 239).

4. Bobbio, Liberalism och demokrati, 1994, s. Iо.

5. "Franska nationalförsamlingens förklaring om de mänskliga och medborgerliga rättigheterna", 1998 [I789], s. I67; jfr Slavoj Žižek som anmärker: "när väl en juridisk ordning är upprättad, raderas dess osäkra och villkorade tillkomst ut. När den väl är här har den alltid redan varit här, varje berättelse om dess ursprung blir till en myt.” Žižek, Living in the end times, 20II, s. 28-29, min övers.

6. Detta framgår redan av den andra artikeln i den franska förklaringen: "Syftet med all samhällelig sammanslutning är att skydda och bevara människans naturliga och omistliga rättigheter." "Franska nationalförsamlingens förklaring ...", 1998 [1789], s. I67. Se även Lindensjö, "Demokrati”, I999, s. I6; Balibar, "On the politics of human rights", 2013, s. 19-20.

7. Marx, "Filosofins elände", I978 [I847], s. 319-320:

Ekonomerna förfar på ett säreget sätt. Det finns för dem endast två slag av institutioner, konstlade och naturliga. Feodalismens institutioner är konstlade, bourgeoisins naturliga. De liknar i detta avseende också teologerna, som också skiljer på två slags religioner. Varje religion, som inte är deras egen, är en uppfinning av människorna, medan deras egen religion är en uppenbarelse av Gud. När ekonomerna säger att de nuvarande förhållandena - de borgerliga produktionsförhållandena - är naturliga vill de därmed låta förstå att det är förhållanden, i vilka rikedomsalstringen och produktivkrafternas utveckling sker i enlighet med naturlagarna. På så sätt är dessa förhållanden själva av tidens inflytande oavhängiga naturlagar. Det är eviga lagar, som alltid måste styra samhället.

Jfr Žižek som menar att argumentet håller även för en kritik av dagens liberaler eller borgare genom att byta ut "feodalism" mot "socialism". Žižek, First as tragedy, then as farce, 2009, s. 2I-22.

8. Locke, Andra avhandlingen om styrelseskicket, 2016 [I689], s. 87, \$89.

9. Balibar, Citizenship, 2015, s. 34-36; Balibar, Citizen subject. Foundations for philosophical anthropology, 20I7, s. 29-37.

Io. Marx, "Om judefrågan", I995 [I844], s. 4I.

I I. Callinicos, Jämlikhet, 2002, s. 26-27; Wallerstein, "Citizens all? Citizens some! The making of the citizen", 2003, s. 65I-666, 670-673. 
I 2. "Förklaring om kvinnans rättigheter", I998 [I79I], s. I72.

I3. "Franska nationalförsamlingens förklaring ...", I998 [I789], s. I67.

I4. Som Sven-Eric Liedman skriver sågs även egendomen som en "avgörande del av friheten”. Liedman, Tankens lätthet, tingens tyngd. Om Frihet, 2004, s. 64.

I 5. Marx I995 [I844], s. 4I-44, 47. Se även Liedman 2004, s. 62-70; Balibar 20I7, s. $276-277$.

I6. Bobbio I994, s. 33 .

I7. Ibid., s. 33 .

I 8. Ibid., s. 34; jfr artikel fyra i den franska förklaringen: "Frihet innebär makt att göra vadhelst som icke skadar någon annan; för utövning av varje människas naturliga rättigheter finns därför inga andra gränser än de, som tillförsäkrar samhällets övriga medlemmar åtnjutandet av samma rättigheter." "Franska nationalförsamlingens förklaring ...", 1998 [I789], s. I68.

I9. Balibar, "Historical dilemmas of democracy and their contemporary relevance for citizenship", 2008, s. 525-526; Balibar 2013, s. 23; Balibar, "Mångtydig universalitet", 20I4, s. 36-38; Balibar 20I5, s. 29-3I; se även Callinicos 2002, s. 27-28.

20. Bobbio I994, s. 33; jfr Callinicos 2002, s. 57.

2 I. Denna utveckling beskrevs av Thomas H. Marshall som i essän "Citizenship and social class" (I950) tecknade medborgarskapets historiska utvecklingssteg, där han bland annat menade att medborgarnas rättigheter gick först från de tidiga civila och politiska till slutligen de sociala rättigheterna. Se Marshall, Citizenship and social class and other essays, I950, s. 27-29; jfr Bobbio, Rättigheternas epok, 200I, s. 38, 73; se även Liedman 2004, s. I09-IIO.

22. Balibar 2008, s. 534-535; Balibar 2015, s. 45-51.

23. Artikel 22 i Allmän förklaring om de mänskliga rättigheterna, 1948.

24. Samtidigt var de sociala rättigheterna även tidigare villkorade. Se Callinicos 2002, s. 97-I03; Balibar 2008, s. 534-536; Balibar 2015, s. 45-51; jfr Vincent, The politics of human rights, 2010 , s. I48-152.

25. Se OECD, OECD Income inequality data update: Sweden, 2015; jfr Callinicos 2002, s. IO8-III.

26. Kristersson, Rättigheter, skyldigheter, möjligheter - lika för alla, 2018a.

27. Moderaterna, Var politik i korthet, 2018a.

28. Kristersson 20I8a, s. I3.

29. Jfr Azar, Den koloniala bumerangen. Från schibbolet till körkort $i$ svenskhet, 2006, s. $87-93$.

30. En grupp moderater lade under oktober månad 2017 fram ett lagförslag om att kunna sätta in militär i förorten. Stefan Löfven, Socialdemokraternas partiledare, liksom Sverigedemokraternas partiledare Jimmie Åkesson reflekterade båda under 
våren 2018 över möjligheten att använda sig av militären i de svenska (men underförstått "invandrartäta") förorterna.

3I. Bobbio 200I, s. 80 .

32. Moderaterna 20I8a; Kristersson 20I8a; Kristersson, "Mitt Sverige", $2018 \mathrm{~b}$.

33. Moderaterna, Om oss, 2oI8b.

34. Kristersson 2018b, s. 5 .

35. Ibid., s. 2.

36. Callinicos 2002, s. IOI.

37. Moderaterna 20I8a.

38. Liedman 2004, s. I05-106.

39. Žižek 2009, s. 62-64.

40. Liedman 2004, s. 106.

4I. Žižek 2009, s. 13; jfr Liedman 2004, s. I06.

42. Som det tydligt framgår av Moderaterna: "Sverige ska vara ett land för hoppfulla. Ett land präglat av företagsamhet, jämlikhet och social rörlighet, där du av egen kraft - men också med andras hjälp - kan ta dig nästan hur långt som helst. Ett land med frihet att välja sitt liv och med all den mångfald som den friheten skapar." Moderaterna 20I8a.

43. Salecl, "Valfrihetssamhället", 20I5, s. II6.

44. Ibid., s. 104 .

45. Brown, Att vinna framtiden àter. Texter om makt och frihet $i$ senmoderniteten, 2008, s. I78-I88; Balibar 20I5, s. III-II2; Salecl 20I5, s. I0O-IO7; Brown, "Sacrificial citizenship: Neoliberalism, human capital, and austerity politics", 20I6, s. 4-5, 8-9; jfr Callinicos 2002, s. 100-102.

46. Han, Trötthetssambället, 2016, s. I6-17 (citat s. I6); se även Han, Eros agoni, 2015, s. 17-19.

47. Kristersson 20I8a, s. 6 .

48. Žižek noterar att de kritiska röster om det ekonomiska räddningspaketet till bankerna i spåren av finanskrisen 2008 som menade att de "vanliga medborgarna" på "Main Street" (i motsats till den ekonomiska eliten på Wall Street) fick bära kostnaderna för bankernas agerande inte tog hänsyn till hur de två är beroende av varandra (även om detta ömsesidiga förhållande givetvis är ojämlikt). Se Žižek 2009, s. I3.

49. Byung-Chul Han anmärker hur "[d]en nyliberala regimen döljer sin tvångsstruktur bakom den skenbara friheten för den enskilda individen, som inte längre uppfattar sig själv som ett underkastat subjekt (subject to), utan som ett självkastande projekt. Det är det som är det finurliga." Prestationssubjektet blir till en självexploatör, som exploaterar sig själv i en process där offer och förövare är densamma. Han 20I5, s. 17-19 (citat s. I8-I9); se även Brown 2008, s. 178-I88; Brown 20I6, s. Io. 
50. Brown 20I6, s. 4, min övers.; jfr Callinicos 2002, s. Ioo.

5I. Kristersson 20I8b, s. 6.

52. Här kan det vara värt att fråga sig vad som räknas som "bidrag" - i vilken mån kan exempelvis RUT-avdrag betraktas som bidrag? Ur ett sådant perspektiv kan föreställningen om "Lika för alla” också ifrågasättas.

53. Brown 20I6, s. 8-II.

54. Moderaterna 20I8b.

55. Arbetslösheten kopplas främst till utrikesfödda som bland annat ska hjälpas genom "inträdesjobb" med låg lön. Se Kristersson 2018a, s. 9-II.

56. Detta framkom redan under Fredrik Reinfeldts tid som partiledare för Moderaterna, när han under sin tid som statsminister försvarade sig mot anklagelser om att det rådde massarbetslöshet i Sverige genom att förklara: "Om man tittar på etniska svenskar mitt i livet så har vi mycket låg arbetslöshet." SVT, "Storm på nätet om Reinfeldts uttalande", 2012.

57. Balibar, We, the people of Europe? Reflections on transnational citizenship, 2004, s. 37, min övers.

58. Ett sådant förhållande är i sig inget nytt. Kvinnor kunde exempelvis tidigare vara medborgare men politiskt sakna rösträtt. Som Michael Azar påpekar blir invandrarskapet, genom betoningen på "äkta svenskhet" och talet om "svenska värderingar", ett slags livstidsdom och ett ständigt utanförskap på gränsen såsom nästan svensk. Se Azar 2006, s. 9I-94, I0I-I09; se även Balibar 2004, s. 40, 44-45, 64-65.

59. Jfr Azar 2006, s. 94-95.

6o. Balibar 2004, s. 33-37, 58-61.

6I. Arendt, Totalitarismens ursprung, 2016 [I95I], s. 374.

62. Kristersson 20I8a, s. 9; jfr Žižek 2009, s. 47-49.

63. Marcuse, "Epilogue to the new German edition of Marx's I8th Brumaire of Louis Napoleon", I969, s. 55.

64. Orwell, Djurens gård. En saga, 1985 [1945], s. I2I.

\section{Referenser}

Allmän förklaring om de mänskliga rättigheterna (1948), från kontoret för FN:s högkommissarie för mänskliga rättigheters, $\mathrm{OHCHR:s,} \mathrm{hemsida.}$

URL: https:/www.ohchr.org/EN/UDHR/Pages/Language.aspx?LangID=swd (II april 20I9)

"Amerikanska självständighetsförklaringen den 4 juli 1776 (Thomas Jeffersons ingress)" (1998 [1776]), i Ambjörnsson, Ronny \& Eriksson, Gunnar (red.) Europeiska urkunder, Natur och Kultur, Stockholm. 
Arendt, Hannah (2016 [195I]) Totalitarismens ursprung, Daidalos, Göteborg.

Azar, Michael (2006) Den koloniala bumerangen. Frän schibbolet till körkort i svenskhet, Östlings bokförlag Symposion, Eslöv.

Balibar, Étienne (2004) We, the people of Europe? Reflections on transnational citizenship, Princeton University Press, Princeton.

Balibar, Étienne (2008) "Historical dilemmas of democracy and their contemporary relevance for citizenship", i Rethinking Marxism, 20, 4, s. 522-538.

DoI: https://doi.org/I0.I080/08935690802299363

Balibar, Étienne (2013) "On the politics of human rights", i Constellations, 20, I, s. I8-26. DoI: https://doi.org/IO.IIII/cons.I20I8

Balibar, Étienne (20I4) "Mångtydig universalitet”, i Fronesis nr 48-49, Det universella.

Balibar, Étienne (2015) Citizenship, Polity, Cambridge.

Balibar, Étienne (2017) Citizen subject. Foundations for philosophical anthropology, Fordham University Press, New York.

Bobbio, Norberto (1994) Liberalism och demokrati, Daidalos, Göteborg.

Bobbio, Norberto (200I) Rättigheternas epok, Daidalos, Göteborg.

Brown, Wendy (2008) Att vinna framtiden åter. Texter om makt och frihet i senmoderniteten, Atlas, Stockholm.

Brown, Wendy (2016) "Sacrificial citizenship: Neoliberalism, human capital, and austerity politics", i Constellations, 23, I, s. 3-I4.

DOI: https://doi.org/IO.IIII/I467-8675.12166

Callinicos, Alex (2002) Jämlikhet, Daidalos, Göteborg.

"Franska nationalförsamlingens förklaring om de mänskliga och medborgerliga rättigheterna" (I998 [1789]), i Ambjörnsson, Ronny \& Eriksson, Gunnar (red.) Europeiska urkunder, Natur och Kultur, Stockholm.

"Förklaring om kvinnans rättigheter" (I998 [I79I]), i Ambjörnsson, Ronny \& Eriksson, Gunnar (red.) Europeiska urkunder, Natur och Kultur, Stockholm.

Han, Byung-Chul (2015) Eros agoni, Ersatz, Stockholm.

Han, Byung-Chul (2016) Trötthetssamhället, ny utgåva, Ersatz, Stockholm.

Kristersson, Ulf (20I8a) Rättigheter, skyldigheter, möjligheter - lika för alla, tal hållet på Moderaternas Sverigemöte I2 maj 2018.

URL: https://moderaterna.se/sites/default/files/page_attachments/20I8-05/UK\%20 Lo\%CC\%88rdag\%20I805I2.pdf (II april 20I9)

Kristersson, Ulf (20I8b) "Mitt Sverige", från programmet Tal till nationen - mitt Sverige 2028, sänt i SVT 30 maj 20I8, manus publicerat på Moderaternas hemsida.

URL: https://moderaterna.se/sites/default/files/page_attachments/20I8-05/mittsverige-tal-20I8-05-30.pdf

Laclau, Ernesto \& Mouffe, Chantal (2008) Hegemonin och den socialistiska strategin, Glänta, Göteborg.

Liedman, Sven-Eric (2004) Tankens lätthet, tingens tyngd. Om Frihet, Bonnier, Stockholm.

Lindensjö, Bo (1999) "Demokrati”, i SOU 1999:77, Demokrati och medborgarskap. Demokratiutredningens forskarvolym II.

Locke, John (2016 [1689]) Andra avhandlingen om styrelseskicket, Daidalos, Göteborg. 
Marcuse, Herbert (1969) "Epilogue to the new German edition of Marx's i8th Brumaire of Louis Napoleon", i Radical America, 3, 4, s. 55-59,

Marshall, Thomas H. (1950) Citizenship and social class and other essays, Cambridge University Press, Cambridge.

Marx, Karl (I978 [I847]) "Filosofins elände”, i Marx, Karl \& Engels, Friedrich, Filosofiska skrifter. Skrifter i urval, Cavefors, Lund.

Marx, Karl (I995 [1844]) "Om judefrågan”, i Marx, Karl, Människans frigörelse, ny, reviderad utgåva, Daidalos, Göteborg.

Mellin, Lena (20I8) ”Nu låter M som sossar igen”, i Aftonbladet II maj 2018. URL: https://www.aftonbladet.se/nyheter/kolumnister/a/qnMiqE/nu-later-m-somsossar-igen (II april 20I9)

Moderaterna (20I8a) Vå politik i korthet, från Moderaternas hemsida, hämtat 2018. URL: https://moderaterna.se/var-politik-i-korthet (2 juni 20I8)

Moderaterna (20I8b) Om oss, från Moderaternas hemsida, hämtat $20 \mathrm{I} 8$. URL: https://moderaterna.se/om-oss (3I maj 2018)

OECD (2015) OECD Income inequality data update: Sweden. URL: http://www.oecd.org/sweden/OECD-Income-Inequality-Sweden.pdf (II april 2019)

Orwell, George (1985 [1945]) Djurens gård. En saga, ny utgåva, Litteraturfrämjandet, Stockholm.

Salecl, Renata (2015) "Valfrihetssamhället", i Fronesis nr 52-53, Ideologi.

SVT (20I2) "Storm på nätet om Reinfeldts uttalande", på SVT Nyheter Is maj 2012.

URL: https:/www.svt.se/nyheter/inrikes/storm-pa-natet-om-reinfeldts-uttalande (I9 mars 20I9)

Vincent, Andrew (2010) The politics of human rights, Oxford University Press, Oxford.

Wallerstein, Immanuel (2003) "Citizens all? Citizens some! The making of the citizen", i Comparative Studies in Society and History, 45, 4, s. 650-679.

DOI: https://doi.org/IO.IOI7/SooI04I7503000318

Žižek, Slavoj (2009) First as tragedy, then as farce, Verso, London.

Žižek, Slavoj (20II) Living in the end times, reviderad utgåva, Verso, London. 


\section{REFORMISM OCH UTOPISM}

Wigforss, efterkrigstid och socialdemokratins framtid

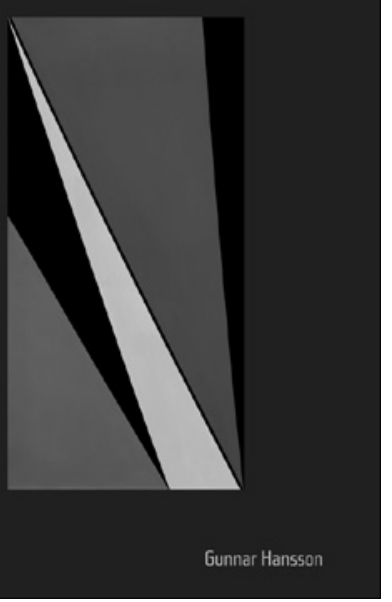

\section{OM SAMHÄLLETS OMVANDLING}

\section{Wigforss och pragmatismens politiska filosofi}

Gunnar Hansson

288 sidor

I Om sambällets omvandling tar Gunnar Hansson upp en förbisedd tanketradition inom svensk socialdemokrati och visar hur stort inflytande den filosofiska pragmatismen hade på Ernst Wigforss politiska idéutveckling.

\section{REFORMISM OCH UTOPISM}

Wigforss, efterkrigstid och socialdemokratins framtid

Gunnar Hansson

I90 sidor

Statsvetaren Gunnar Hansson har i flera böcker behandlat den svenska socialdemokratins ledande teoretiker Ernst Wigforss tänkande. Reformism och utopism handlar om Wigforss försök att utforma en vision för politiskt tänkande och handlande i syfte att skapa ett annat och bättre samhälle.

\section{OM SAMHÄLLETS OMVANDLING}

Wigforss och pragmatismens politiska filosofi

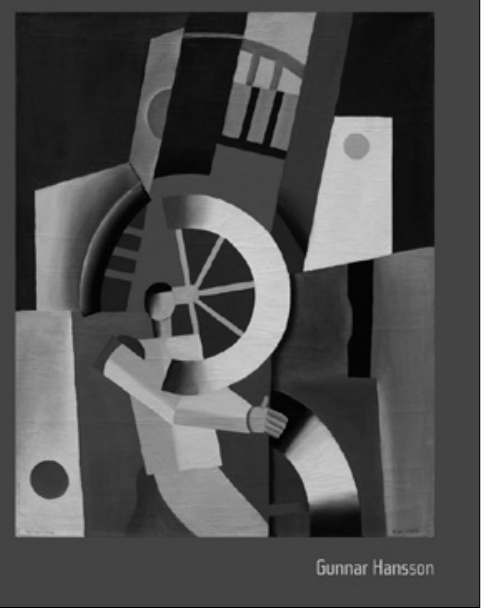

»Böckerna går att beställa i bokhandeln och från www.arkiv.nu« 


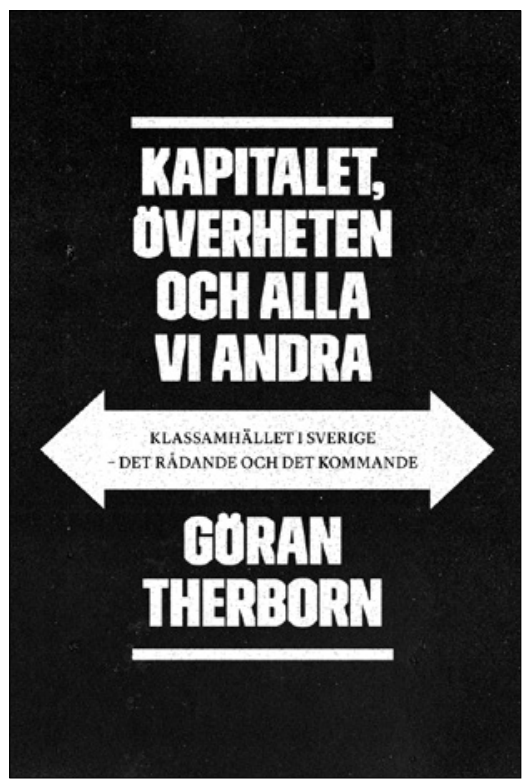

\section{GÖRAN THERBORN TAR SIG AN DEN SKENANDE OJÄMLIKHETEN I SVERIGE}

Kapitalet, överheten och alla vi andra. Klassambället i Sverige - det rådande och det kommande

$$
\text { I76 sidor }
$$

Therborns omtalade uppgörelse med det svenska klassamhället av idag.

\section{OCH I VÄRLDEN}

Ojämlikhet dödar

2I2 sidor

Göran Therborns internationella studie av ojämlikhetens dödliga effekter i såväl fattiga som rika länder (på engelska The Killing Fields of Inequality). Boken placerar in den svenska utvecklingen som tecknas i Kapitalet, överheten och alla vi andra i en global kontext.

Tillsammans skildrar de båda verken på ett klargörande sätt en av vår tids största ödesfrågor.

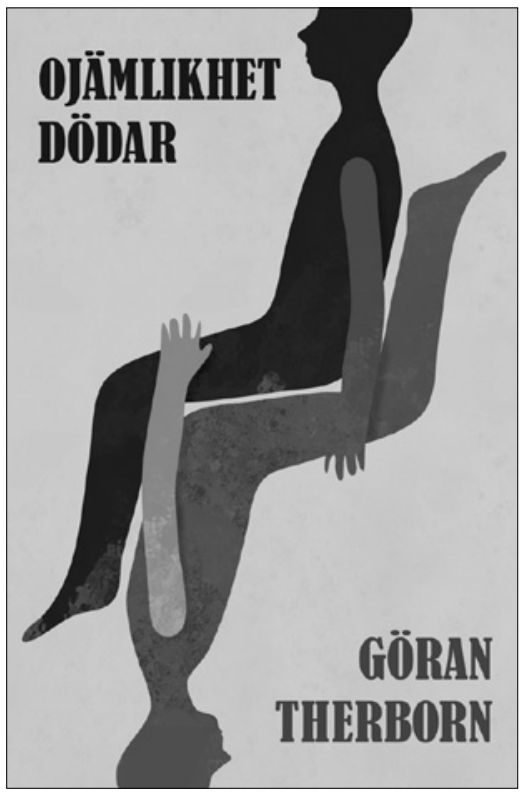

"BÖCKERNA GÅR ATT BESTÄLLA I BOKHANDELN OCH FRÅN WWW.ARKIV.NU“ 